\title{
Oxidative aging and cloud condensation nuclei activation of laboratory combustion soot
}

\author{
A. T. Lambe*,a,b, A. T. Ahern ${ }^{a, b, 1}$, J. P. Wright ${ }^{a}$, D. R. Croasdale ${ }^{a}$, P. \\ Davidovits $^{\mathrm{a}}$, T. B. Onasch ${ }^{* *, a, b}$ \\ ${ }^{a}$ Chemistry Department, Boston College, Chestnut Hill, Massachusetts, 02467, USA \\ ${ }^{b}$ Aerodyne Research, Inc., Billerica, Massachusetts, 01821, USA
}

\begin{abstract}
Radiative forcing by aerosol particles containing black carbon (BC) may be positive or negative depending on specific atmospheric conditions. Black carbon itself absorbs solar radiation and thereby heats the surrounding environment. On the other hand, as a result of atmospheric aging, BC-containing particles may become hydrophilic due to oxidation, condensation, and/or coagulation of water-soluble material. The aged particles can act as cloud condensation nuclei $(\mathrm{CCN})$ and contribute to cloud formation that may result either in cooling or heating. In this work, through a series of laboratory experiments, we investigate the transformation of soot particles from hydrophobic to hydrophilic and estimate the atmospheric residence time required for this transformation. Ethylene flame-generated soot particles were size-selected and exposed to $\mathrm{OH}$ radicals in a Potential Aerosol Mass flow
\end{abstract}

${ }^{*}$ Corresponding author

** Principal corresponding author

Email addresses: lambe@aerodyne.com (A. T. Lambe), aahern@andrew.cmu.edu (A. T. Ahern), paul.davidovits@bc.edu (P. Davidovits), onasch@aerodyne.com (T. B. Onasch)

${ }^{1}$ Now at: Center for Atmospheric Particle Studies, Carnegie Mellon University, Pittsburgh, Pennsylvania, 15232, USA 
reactor. Aging was simulated via $\mathrm{OH}$ exposures equivalent to atmospheric lifetimes over a range from hours to multiple days. The chemical composition of the organic coatings as a function of $\mathrm{OH}$ exposure was monitored with an Aerodyne Aerosol Mass Spectrometer. The CCN activity of the aged soot particles was measured as a function of $\mathrm{OH}$ exposure and chemical composition. Experimental measurements indicate that heterogenous $\mathrm{OH}$ oxidation of initially CCN-inactive nascent soot produces CCN-active particles. Critical supersaturations at integrated $\mathrm{OH}$ exposures equivalent to $0.4,2$, and 10 days are $2.1 \%, 0.82 \%$, and $0.40 \%$. Corresponding values for the effective hygroscopicity parameter, $\kappa_{\text {eff }}$, ranged from $\kappa_{\text {eff }}<8 \times 10^{-4}$ to $\kappa_{\text {eff }}=0.09$ as a function of $\mathrm{OH}$ exposure. Condensation of hydrophilic organic or inorganic coatings (produced from oxidation of gas-phase precursors introduced to the flow reactor) on soot particles speeds up the CCN activation by a factor of 6 to 50 depending on the nature and thickness of the coating. The results suggest that $\mathrm{CCN}$ activation of atmospheric BC-containing particles is primarily due to secondary coatings.

Key words:

soot, oxidative aging, cloud condensation nuclei

\section{1. Introduction}

2 Aerosol particles affect climate through direct and indirect interactions 3 (Mahowald, 2011). Direct interactions consist of scattering or absorption by

4 the particles of solar radiation. Indirect interactions are due to the role of 5 hydrophilic aerosols in cloud formation and cloud lifetime. Clouds may either 6 cool or warm the atmosphere depending on atmospheric conditions. 
While the climate impact of inorganic components of aerosol particles (e.g. sulfates, nitrates, and mineral dust) is reasonably well understood, aerosol particles containing organic and $\mathrm{BC}$ components are not adequately characterized for reliable assessment of their climate effects. The interaction of particles containing absorbing material such as black carbon (BC) is especially complex. Black carbon absorbs solar radiation and thereby heats the surrounding environment, leading to atmospheric warming and surface dimming (Reddy and Boucher, 2007; Ramanathan and Carmichael, 2008: Andreae and Ramanathan, 2013). On the other hand, as a result of atmospheric aging processes, hydrophobic BC-containing particles may become hydrophilic due to oxidation of initially present hydrophobic coatings (Chughtai et al., 1996, 1999; Zuberi, 2005), condensation of hydrophilic material, (Hings et al., 2008; Khalizov et al. 2009; Tritscher et al., 2011; Qiu et al., 2012; Khalizov et al. 2013), or through coagulation with hydrophilic particles (Hagen et al., 1991; Podzimek et al., 1991; Fierce et al., 2013). In this way, BC-containing particles become cloud condensation nuclei (CCN). In the absence of aging processes, fresh $\mathrm{BC}$ particles containing hydrophilic coatings (e.g. produced from combustion of fuels with sufficient sulfur content; Gysel (2003)) may also contribute to CCN formation. The CCN-activated soot particles contribute to cloud formation resulting in cooling or warming depending on atmospheric conditions and soot content. CCN activation may also affect particle atmospheric lifetime via wet deposition.

The deliquescence of soot particles coated with hydrophilic organics approaches the hygroscopicity of the pure organics at large coating thickness (Hings et al., 2008; Wittbom et al., 2014). However, these previous studies 
have not directly connected changes in soot chemical composition and photochemical age to changes in CCN activity. Thus, the available data are not readily implemented in climate models. To date, models typically simulate aging of soot using highly simplified parameterizations because the dependence of BC hygroscopicity on physicochemical properties is highly uncertain. For example, Cooke et al. (1999) assumed conversion of hydrophobic BC to hydrophilic BC takes 1.15 days, a timescale that has been widely used in modeling BC aging processes (Chin et al., 2002). However, recent field studies suggest that this conversion can occur over significantly faster timescales (Moffet and Prather, 2009; Schwarz et al., 2010; Cheng et al., 2012).

The present work is focused on quantitatively relating oxidative and condensational aging to CCN activity of soot particles. Laboratory generated ethylene flame soot particles were exposed to $\mathrm{OH}$ radicals in a flow reactor. Aging was simulated via $\mathrm{OH}$ exposures equivalent to atmospheric lifetimes over a range from hours to multiple days. The chemical composition of the organic coatings as a function of $\mathrm{OH}$ exposure was measured with an aerosol mass spectrometer. The CCN activity of the aged soot particles was measured as a function of $\mathrm{OH}$ exposure and chemical composition. Experiments were performed with both nascent soot and soot particles coated by secondary organic aerosol (SOA) representative of biogenic and anthropogenic compounds found in the atmosphere and by sulfuric acid. The coatings were produced from oxidation of gas-phase precursors added to the flow reactor along with the soot. The measurements were used to estimate, under a range of atmospherically relevant conditions, residence times required for $\mathrm{BC}$ containing particles to become $\mathrm{CCN}$-active and to formulate values for the 
effective hygroscopicity parameter $\kappa_{\text {eff }}$.

\section{Materials and Methods}

Figure 1 is a schematic of the experimental setup showing soot generation, oxidation, monitoring and characterization.

\subsection{Soot Generation}

Soot particles were generated using a premixed flat burner flame as described in detail elsewhere (Slowik et al., 2007, Cross et al., 2010). Briefly, premixed flows of ethylene, oxygen, and nitrogen gases are delivered through a McKenna flat burner at a total flow of $9 \mathrm{~L} / \mathrm{min}$, with a fuel-to-air ratio, $\phi=2.00 \pm 0.05$. A mini-eductor (Fox Valves) extracts a flow of polydisperse soot particles from the tip of the flame into the differential mobility analyzer (DMA, TSI 3081) to select monodisperse soot particles. The flow passes into a charcoal denuder to remove gas-phase organics.

\subsection{Particle Processing}

Soot particles were exposed to $\mathrm{OH}$ radicals in a Potential Aerosol Mass (PAM) flow reactor (Kang et al., 2007; Lambe et al., 2011a). The average residence time was approximately $100 \mathrm{sec}$, and the level of processing (i.e. exposure time) was controlled by the $\mathrm{OH}$ concentration in the reactor. $\mathrm{OH}$ radicals were produced via the reaction $\mathrm{O}\left({ }^{1} \mathrm{D}\right)+\mathrm{H}_{2} \mathrm{O} \rightarrow 2 \mathrm{OH}$, with $\mathrm{O}\left({ }^{1} \mathrm{D}\right)$ radicals produced via the photodissociation $\mathrm{O}_{3}+\mathrm{h} \nu \rightarrow \mathrm{O}_{2}+\mathrm{O}\left({ }^{1} \mathrm{D}\right)$. The UV light was produced by four mercury lamps (BHK Inc.) inside the PAM reactor with peak emission intensity at $\lambda=254 \mathrm{~nm}$. These lamps were mounted in teflon-coated quartz cylindrical sleeves and were continually purged with 
$\mathrm{N}_{2}$. $\mathrm{O}_{3}$ was generated outside the PAM reactor by irradiating $\mathrm{O}_{2}$ with a mercury lamp $(\lambda=185 \mathrm{~nm})$. Water vapor was introduced using a heated Nafion membrane humidier (Perma Pure LLC). The humidifier temperature was set to provide a controlled relative humidity $(\mathrm{RH})$ in the range of $24 \%-30 \%$.

The $\mathrm{OH}$ concentration was determined by measuring the decay of $\mathrm{SO}_{2}$ due to the well-characterized reaction with $\mathrm{OH}$ (Davis et al., 1979). The $\mathrm{OH}$ exposure is the product of the $\mathrm{OH}$ concentration and the average residence time in the PAM reactor. The $\mathrm{OH}$ concentration was varied by changing the UV light intensity by step-wise changing the lamp voltages. The depletion of $\mathrm{OH}$ within the PAM reactor due to reactions with aerosol particles is negligible (less than $\sim 5 \%$ ). The $\mathrm{OH}$ exposures ranged from $4.9 \times 10^{10}$ to $1.3 \times 10^{12}$ molec $\mathrm{cm}^{-3} \mathrm{~s}$; approximately equivalent to 0.4 to 10 days of atmospheric exposure at a $\mathrm{OH}$ concentration of $1.5 \times 10^{6}$ molec $\mathrm{cm}^{-3}$ typical of 24 hour-averaged continental OH levels (Mao et al., 2009). In the experiments studying the effect of secondary organic aerosol and sulfuric acid coatings, gas-phase $\alpha$-pinene, $m$-xylene, or $\mathrm{SO}_{2}$ was introduced along with the soot to produce SOA or sulfuric acid via $\mathrm{OH}$ oxidation inside the PAM reactor. The $\alpha$-pinene and $m$-xylene precursors were chosen as surrogate species for biogenic and anthropogenic emissions, respectively. The oxidized vapors formed a deposition coating on the soot particles.

\subsection{Particle Monitoring and Characterization}

Particle mobility size distributions were measured with a scanning mobility particle sizer (SMPS, TSI 3080). Mass spectra and aerodynamic size distributions of the non-refractory component were measured with an Aerodyne compact time-of-flight aerosol mass spectrometer (c-ToF-AMS) (Drewnick 
et al., 2005). The CCN activation of soot particles was measured using a continuous flow CCN counter (CCNC, Droplet Measurement Technologies) (Roberts and Nenes, 2005; Lance et al., 2006). Prior to CCN measurements, the aerosol was size-selected by a DMA, after which CCN activation curves were generated by systematically varying the CCNC column temperature gradient to obtain controlled water vapor supersaturation between $0.1-1.8 \%$.

\section{Results and Discussion}

\subsection{Mass spectra of nascent and oxidized flame soot}

Figure 2 shows typical AMS spectra of organics associated with nascent and oxidized flame soot, respectively. To present the spectra on the same scale, signals at $m / z>90$ are scaled by a factor of 40 . All signals are normalized to the particle mass $\left(\mathrm{M}_{p}\right)$ which was calculated using the mass concentration measured by the c-ToF-AMS and the integrated number concentration measured by the SMPS. Combined AMS and SMPS measurements suggest that under the flame conditions used in the current experiments the nonrefractory component comprises $5 \%-10 \%$ of $\mathrm{M}_{p}$, with the remaining mass consisting of $\mathrm{BC}$ that is not directly detected with the c-ToF-AMS. The spectrum shown in Figure 20 was generated at the maximum $\mathrm{OH}$ exposure used in these experiments $\left(1.3 \times 10^{12}\right.$ molec $\left.\mathrm{cm}^{-3} \mathrm{~s}\right)$. The mass spectra shown in Fig. 2 have a regularly spaced pattern of aromatic fragments from $m / z$ $=198$ to 374 (purple sticks in figure) characteristic of unoxidized polycyclic aromatic hydrocarbons (NIST Chemistry Webbook) and their accompanying doubly-charged ions which contribute to signals measured $m / z=99$ to 187. Additional contributions from aliphatic ions were also present and are 
commonly observed in flame soot (Cain et al. 2010). Figures $2 \mathrm{~b}$ and $2 \mathrm{c}$ show that the oxidized organics are dominated by $m / z=44\left(\mathrm{CO}_{2}^{+}\right)$, which is a mass spectral fragment of organic carboxylic acids measured in the AMS (Aiken et al., 2008).

A comparison of Figures $2 \mathrm{a}, 2 \mathrm{~b}$ and $2 \mathrm{k}$ shows a clearly evident feature of the mass spectra: the oxidative loss of polycyclic aromatic hydrocarbons (PAHs). Mass spectra such as shown in Figure 2 were obtained for three OH exposures: $4.9 \times 10^{10}, 2.5 \times 10^{11}$ and $1.3 \times 10^{12}$ molec $\mathrm{cm}^{-3} \mathrm{~s}$. The effect of $\mathrm{O}_{3}$ on the mass spectrum of the soot was similar to the effect of $\mathrm{OH}$ but significantly smaller. For the spectra shown in Figure2, the mass-per-particle of PAHs $\left(\mathrm{M}_{p, P A H}\right)$ decreases as a function of $\mathrm{OH}$ exposure from $0.011 \mathrm{fg}$ for nascent soot to 0.0041 fg for oxidized soot. This corresponds to a decrease in the total mass fraction of PAHs from 0.0059 to 0.0020 , and a decrease in the non-refractory mass fraction of PAHs from 0.31 to 0.026 . On the other hand, the mass per particle of non-refractory organics exclusive of PAH compounds $\left(\mathrm{M}_{p, n P A H}\right)$ increases from 0.023 fg for nascent soot to 0.15 fg for oxidized soot, or an increase in the total mass fraction of non-PAH organics from 0.013 to 0.076, and an increase in the non-refractory mass fraction from 0.69 to 0.97 . This increase in $\mathrm{M}_{p, n P A H}$ as a function of $\mathrm{OH}$ exposure is larger than the decrease in $\mathrm{M}_{p, P A H}$. Because no volatile organic compounds (VOCs) were added with the $\mathrm{BC}$ in these experiments to produce $\mathrm{SOA}$, this net increase in non-refractory $\mathrm{M}_{p}$ may be explained by functionalization of surface-bound $\mathrm{PAH} /$ aliphatic compounds to organic acids. 


\section{2. $C C N$ activity of oxidized soot}

Figure 3 shows the CCN activation ratio of plotted as a function of water vapor supersaturation in the range from $0.1 \%$ to $1.8 \%$. The mobility diameter of the soot particles prior to activation was $222 \mathrm{~nm}$, corresponding to a volume equivalent diameter $\left(D_{\text {ve }}\right)$ of approximately $124 \mathrm{~nm}$ (see Section 3.3). CCN activation curves for flame soot particles were obtained for three $\mathrm{OH}$ exposures; $4.9 \times 10^{10}, 2.5 \times 10^{11}$ and $1.3 \times 10^{12}$ molec $\mathrm{cm}^{-3} \mathrm{~s}$ as shown. The figure also shows the calculated CCN activation of ammonium sulfate particles with $D_{\mathrm{ve}}=124 \mathrm{~nm}$ (Petters and Kreidenweis, 2007) and CCN activation measurements for nascent (unoxidized) soot and soot exposed to $\sim 20 \mathrm{ppm}$ $\mathrm{O}_{3}$, or an integrated $\mathrm{O}_{3}$ exposure of about $5 \times 10^{16}$ molec $\mathrm{cm}^{-3} \mathrm{~s}$, which is the level of $\mathrm{O}_{3}$ used to generate $\mathrm{OH}$. This integrated $\mathrm{O}_{3}$ exposure was obtained in the dark with the lamps turned off and corresponds to 1.25 days of equivalent ambient $\mathrm{O}_{3}$ oxidation at a typical average $\mathrm{O}_{3}$ concentration of $5 \times 10^{11}$ molec $\mathrm{cm}^{-3}$ (20 ppb) (Hough and Derwent, 1990). As expected, nascent soot is CCN-inactive in the range of supersaturations studied (up to 1.8\%). Below a supersaturation of about $1 \%, \mathrm{CCN}$ activation of soot particles exposed to ozone at the ozone concentration used in our studies is small. Subsequent data are corrected for partial activation of soot by $\mathrm{O}_{3}$ oxidation. CCN activation curves such as shown in Figure 3 are usually characterized by the critical supersaturation, $s_{c}$, at which the Kelvin effect exceeds the solute effect leading to spontaneous growth of a particle to become a cloud droplet. As is usual, $s_{c}$ is designated by water vapor supersaturation at which the activation ratio equals 0.5 .

Figure 4 a shows $s_{c}$ obtained from data in Figure 3 for oxidized soot as 
a function of $\mathrm{OH}$ exposure (lower axis). The upper axis shows the equivalent photochemical age in days assuming an average $\mathrm{OH}$ concentration of $1.5 \times 10^{6}$ molec $\mathrm{cm}^{-3}$. In this figure, the contribution of the $\mathrm{O}_{3}$ oxidation to CCN activation was taken into account by subtracting the activation ratio of soot particles exposed to $\mathrm{O}_{3}$ below $s_{c}=1 \%$ from all other CCN activation curves. This correction was significant only for the lowest $\mathrm{OH}$ exposure studied and was necessary because $\mathrm{O}_{3}$ uptake by PAHs on the soot was significant compared to $\mathrm{OH}$ uptake at this condition (Bertram et al., 2001; Gross and Bertram, 2008; Shiraiwa et al., 2009; Bedjanian et al., 2010). The solid line in the figure is a power law fit to the three points shown. Figure 4 a shows that $s_{c}$ of oxidized soot within $0.1 \%$ of the minimum $s_{c}$ that was measured (corresponding to maximum CCN activation) after approximately 6 days of equivalent atmospheric exposure at the assumed $\mathrm{OH}$ concentrations.

\subsection{Effective hygroscopicity parameter $\left(\kappa_{\mathrm{eff}}\right)$ values of oxidized soot}

The dependence of CCN activation of a particle on chemical composition (in our case level of oxidation via $\mathrm{OH}$ exposure) can be expressed in terms of a parameter $\kappa$ that is often used in global models to represent hygroscopicity. This parameter is obtained via the $\kappa$-Köhler equation (Petters and Kreidenweis, 2007, Sullivan et al., 2009) and is defined for a spherical particle by Equation 1:

$$
\kappa=\frac{4 \mathrm{~A}^{3}}{27 \mathrm{D}_{\mathrm{d}}^{3} \ln ^{2} \mathrm{~S}_{\mathrm{c}}} ; \mathrm{A}=\frac{4 \sigma_{\mathrm{w}} \mathrm{M}_{\mathrm{w}}}{\mathrm{RT} \rho_{\mathrm{w}}}
$$

Here $s_{c}$ is the previously defined critical supersaturation, expressed as a fraction rather than a percentage; $D_{d}$ is the droplet diameter of the dry particle, 
$M_{w}$ is the molecular weight of water, $R$ is the universal gas constant, $T$ is the temperature, and $\rho_{w}$ is the density of water; $A$ is a constant equal to $2.1 \times 10^{9} \mathrm{~m}$ assuming the liquid water surface tension of $0.072 \mathrm{~J} \mathrm{~m}^{-2}$ at $T=$ $298 \mathrm{~K}$. We note that $\kappa$-Köhler theory implicitly accounts for multiple soluble and insoluble components in a mixed particle. Here, because black carbon is insoluble, we note that our calculated $\kappa$-values are instead overall effective $\kappa$-values $\left(\kappa_{\text {eff }}\right)$ that are the linear combination of the different components' volume-fraction-weighted $\kappa$-values.

The $\kappa$-values as formulated in Equation 1 are a function of the diameter of a spherical particle. However, the value of the diameter to be used for fractal soot particles is not evident. SMPS and AMS measurements yield the mobility and vacuum aerodynamic diameter values, $D_{m}$ and $D_{v a}$ that are functional expressions rather than geometric parameters. Using $D_{m}$ and $D_{v a}$, the volume equivalent diameter $D_{v e}$ can be calculated defined as the volume of a sphere with the same volume as the particle. In the absence of more detailed information, we will, as is usual (Tritscher et al., 2011; Liu et al., 2013; Wittbom et al., 2014), use the volume equivalent diameter $\left(D_{v e}\right)$ in calculating $\kappa_{\text {eff }}$. In our experiments $D_{v e} \approx 124 \pm 6 \mathrm{~nm}$ and did not change substantially in the course of oxidation. Equations used to calculate $D_{v e}$ are presented in Appendix A. Each of the $s_{c}$ values measured as a function of $\mathrm{OH}$ exposure can yield a value of $\kappa_{\text {eff }}$ via Equation 1 .

In Figure $4 \mathrm{~b}$, we show $\kappa_{\text {eff }}$ as a function of $\mathrm{OH}$ exposure and photochemical age calculated using Equation 1 with $s_{c}$ as shown in Figure $4 a$ and $D_{v e}$

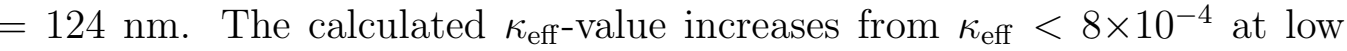
$\mathrm{OH}$ exposure to $\kappa_{\text {eff }}=0.09$ at the highest $\mathrm{OH}$ exposure, compared to $\kappa_{\text {eff }} \approx$ 
$0.1-0.2$ for hydrophilic organic compounds and secondary organic aerosol (SOA) (Petters et al., 2009; Lambe et al., 2011b; Mei et al., 2013; Rickards et al. 2013). Equation 1 illustrates the size dependence of CCN activation of oxidized soot particles. Figure $4 \mathrm{c}$ shows calculated $s_{c}$ values obtained from

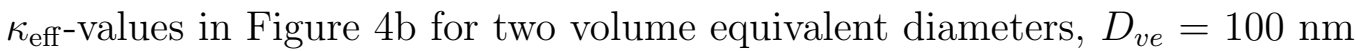
and $D_{v e}=200 \mathrm{~nm}$, used here as reference values for urban and remote BC, respectively (Schwarz et al., 2006, Liu et al., 2010; Ohata et al., 2013; Schwarz et al. 2013). At one day of equivalent atmospheric oxidation, calculated $s_{c}$ values range from $0.6 \%\left(D_{v e}=200 \mathrm{~nm}\right)$ to $1.7 \%\left(D_{v e}=100 \mathrm{~nm}\right)$. Similar size dependence is predicted at other $\mathrm{OH}$ exposures with the simplifying assumption that the heterogeneously oxidized surface-to-BC volume ratio remains constant as a function of particle size. Typical maximum supersaturations in atmospheric cumulus clouds range from $0.3 \%$ to $0.8 \%$ Pruppacher and Klett, 1980).

\subsection{Effect of SOA and sulfuric acid coatings on $C C N$ activation of soot}

In a subset of experiments, $\mathrm{SO}_{2}, \alpha$-pinene or $m$-xylene was introduced along with soot into the PAM reactor. These species were oxidized in the gas phase to produce sulfuric acid or SOA, which condensed to coat the soot. The coating thickness ranged from approximately 2 to $66 \mathrm{~nm}$. While the same mobility diameter was always size-selected prior to CCN measurements independent of coating thickness $\left(D_{m} \sim 222 \mathrm{~nm}\right)$, coating the soot with sulfuric acid or SOA increases $D_{v a}$, and, consequently, $D_{v e}$, though only changing the soot core mass slightly.

Figure 5 shows $s_{c}$ as a function of $\mathrm{OH}$ exposure for soot particles coated with sulfuric acid or SOA produced by oxidation of gas phase $\alpha$-pinene and 
$m$-xylene. The coating thickness is designated by color as shown in the figure. The solid line is the critical supersaturation for uncoated soot duplicated from Figure $4 a$. The effects of sulfuric acid and SOA coatings on $s_{c}$ were measured at three $\mathrm{OH}$ exposures and varied coating thickness. Figure 5 shows that $s_{c}$ for coated soot is lower than for uncoated soot at a specific OH exposure, as expected (Hings et al., 2008; Tritscher et al., 2011; Qiu et al., 2012; Khalizov et al., 2013; Ma et al., 2013). Ozone is highly efficient at oxidizing $\alpha$-pinene. This is made evident by the fact that CCN activation of soot coated with SOA formed from $\alpha$-pinene ozonolysis alone occurs at $s_{c}=0.37 \%$ and does not increase substantially with $\mathrm{OH}$ exposure. Not surprisingly, sulfuric acid coatings are highly effective at reducing the critical supersaturation of soot particles; the theoretical $s_{c}=0.11 \%$ for pure ammonium sulfate particles with $\mathrm{D}_{v e}=124 \mathrm{~nm}$ is shown for reference assuming $\kappa=0.6$ (Petters and Kreidenweis, 2007). Figure 5 suggests that soot particles studied in this work are maximally activated by an SOA coating thickness of $50 \mathrm{~nm}$ or less, or a sulfuric acid coating thickness of $10 \mathrm{~nm}$ or less.

\section{Atmospheric Implications}

Average reported nanoparticle growth rates range from approximately 2 to $5 \mathrm{~nm} / \mathrm{hr}$ (clean rural) and 7 to $18 \mathrm{~nm} / \mathrm{hr}$ (polluted urban) (Yli-Juuti et al. 2011; Pierce et al., 2012; Westervelt et al., 2013). Corresponding atmospheric timescales to achieve these organic coating thicknesses leading to maximal CCN activation are about $10-25 \mathrm{hr}$ in clean air and $3-7 \mathrm{hr}$ in polluted air, or a factor of $6-50$ times faster than a similar level of CCN activity reached by soot particles that were oxidized by $\mathrm{OH}$ ( $\sim 6$ days). Regardless of whether the 
decrease in $s_{c}$ following SOA condensation occurs because of changes in the volume fraction or hygroscopicity (i.e., $\kappa$ ) of either the soot or soluble coating (or both), the relative timescales of these aging processes suggest that under typical conditions, increases in hygroscopicity of $\mathrm{BC}$-containing particles in the atmosphere leading to $\mathrm{CCN}$ activation are dominated by condensation of secondary coatings rather than heterogenous oxidation. Our laboratory measurements support recent field studies suggesting that $\mathrm{CCN}$ activation of $\mathrm{BC}$ particles is dependent upon SOA formation/deposition rates, and may occur pn timescale of hours (Moffet and Prather, 2009; Schwarz et al., 2010; Cheng et al., 2012), implying that the climate impacts of BC-containing particles may be substantially different than predicted by current models. Our results can be used as inputs to models to refine $\mathrm{CCN}$ and lifetime predictions of freshly coated BC-containing particles as a function of atmospheric age and SOA coating thickness.

Acknowledgements. This work was supported by the Atmospheric Chemistry Program of the National Science Foundation, grants No. AGS-1244918 and No. ATM-0854916 to Boston College and AGS-1244999 and AGS0904292 to Aerodyne Research, Inc. We also acknowledge Office of Science (BER), Department of Energy (Atmospheric Systems Research) grants No. DE-SC0006980, DE-SC0011935 and DE-FG02-05ER63995, and EPA STAR grant No. 83503301. We thank Prof. Jesse Kroll (MIT), Prof. Colette Heald (MIT) Dr. Eleanor Browne (MIT), and Dr. Douglas Worsnop (ARI) for helpful discussions, and we thank the reviewers of this manuscript for their helpful comments. 


\section{A. Soot particle volume equivalent diameter calculations}

Some information about effects of oxidation, denuding, and coating of the soot particles is provided by the dynamic shape factor, $\chi$ (Slowik et al. 2007):

$$
\chi=\frac{\text { Drag on particle }}{\text { Drag on sphere of equal volume }}
$$

By definition, $\chi=1$ for a spherical particle.

In the free-molecular flow regime, $\chi$ is related to the particle vacuum aerodynamic diameter $D_{v a}$ and the volume equivalent diameter, $D_{v e}$, defined as the volume of a sphere with the same volume as the particle. The relationship is shown in Equation 3 :

$$
\mathrm{D}_{\mathrm{va}}=\mathrm{D}_{\mathrm{ve}} \frac{\rho_{\mathrm{p}}}{\rho_{0}} \frac{1}{\chi_{\mathrm{v}}}
$$

where $\rho_{p}$ is the particle density, $\rho_{0}$ is unit density $\left(1 \mathrm{~g} \mathrm{~cm}^{-3}\right)$, and $\chi_{v}$ is the dynamic shape factor in the free-molecular flow regime.. We assumed $\rho_{\mathrm{p}}=$ $1.8 \mathrm{~g} \mathrm{~cm}^{-3}$ for black carbon, $\rho_{\mathrm{p}}=1.3 \mathrm{~g} \mathrm{~cm}^{-3}$ for PAHs, $\rho_{\mathrm{p}}=1.4 \mathrm{~g} \mathrm{~cm}^{-3}$ for non-PAH organics, and $\rho_{\mathrm{p}}=1.77 \mathrm{~g} \mathrm{~cm}^{-3}$ for sulfates. The particle mobility diameter, $D_{m}$, is measured by the SMPS and is related to $D_{v e}$ as shown in Equation 4

$$
\mathrm{D}_{\mathrm{m}}=\mathrm{D}_{\mathrm{ve}} \frac{\mathrm{C}_{\mathrm{c}}\left(\mathrm{D}_{\mathrm{m}}\right)}{\mathrm{C}_{\mathrm{c}}\left(\mathrm{D}_{\mathrm{ve}}\right)} \chi_{\mathrm{t}}
$$

The $C_{c}(D)$ parameters are the Cunningham slip correction factors, which account for the reduced drag on a particle in the transition and free-molecular flow regimes; $\chi_{t}$ is the dynamic shape factor in the transition regime. The 
measured quantities $-D_{v a}$ and $D_{m}$, and the mass of the non-refractory components of the soot particles - are used in a system of equations to determine particle mass, particle density, volume, and dynamic shape factor (assuming $\left.\chi=\chi_{v}=\chi_{t}\right)$ as shown in Equations $5-7$

$$
\begin{gathered}
\mathrm{d}_{\mathrm{va}}=\frac{\mathrm{d}_{\mathrm{ve}}}{\chi \rho_{0}}\left(\frac{\mathrm{M}_{\mathrm{BC}}+\mathrm{M}_{\mathrm{PAH}}+\mathrm{M}_{\mathrm{AL}}}{\frac{\mathrm{M}_{\mathrm{BC}}}{\rho_{\mathrm{BC}}}+\frac{\mathrm{M}_{\mathrm{PAH}}}{\rho_{\mathrm{PAH}}}+\frac{\mathrm{M}_{\mathrm{AL}}}{\rho_{\mathrm{AL}}}}\right) \\
\frac{\mathrm{M}_{\mathrm{BC}}}{\rho_{\mathrm{BC}}}+\frac{\mathrm{M}_{\mathrm{PAH}}}{\rho_{\mathrm{PAH}}}+\frac{\mathrm{M}_{\mathrm{AL}}}{\rho_{\mathrm{AL}}}=\frac{\pi}{6} \times \mathrm{d}_{\mathrm{ve}}^{3} \\
\mathrm{M}_{\mathrm{p}}=\mathrm{C} \times \mathrm{d}_{\mathrm{m}}^{\mathrm{D}_{\mathrm{f}}}
\end{gathered}
$$

Here $M_{p}$ is the mass per particle, $\rho$ is the material density of the particle components, and $D_{f}$ is the mass mobility exponent. The subscripts 'BC', 'PAH', and 'AL' refer to black carbon, polycyclic aromatic hydrocarbon, and aliphatic hydrocarbon components, respectively. We derived $\chi$-values ranging from 2.47 to 2.88 for nascent soot and 2.21 to 2.71 for oxidized soot in the absence of SOA formation, whereas SOA-coated soot had $\chi$-values ranging from 1.07 to 2.42 .

\section{References}

Aiken, A., Decarlo, P., Kroll, J., Worsnop, D., Huffman, J., Docherty, K., Ulbrich, I., Mohr, C., Kimmel, J., Sueper, D., 2008. O/C and OM/OC ratios of primary, secondary, and ambient organic aerosols with high-resolution time-of-flight aerosol mass spectrometry. Environmental Science and Technology 42 (12), 4478-4485. 
Andreae, M. O., Ramanathan, V., 2013. Climate's Dark Forcings. Science 340 (6130), 280-281.

Bedjanian, Y., Nguyen, M. L., Le Bras, G., 2010. Kinetics of the reactions of soot surface-bound polycyclic aromatic hydrocarbons with the $\mathrm{OH}$ radicals. Atmospheric Environment 44 (14), 1754-1760.

Bertram, A., Ivanov, A., Hunter, M., Molina, L., Molina, M., 2001. The reaction probability of $\mathrm{OH}$ on organic surfaces of tropospheric interest. The Journal of Physical Chemistry A 105 (41), 9415-9421.

Cain, J. P., Gassman, P. L., Wang, H., Laskin, A., 2010. Micro-FTIR study of soot chemical composition - evidence of aliphatic hydrocarbons on nascent soot surfaces. Physical Chemistry Chemical Physics 12 (20), 5206-5218.

Cheng, Y. F., Su, H., Rose, D., Gunthe, S. S., Berghof, M., Wehner, B., Achtert, P., Nowak, A., Takegawa, N., Kondo, Y., Shiraiwa, M., Gong, Y. G., Shao, M., Hu, M., Zhu, T., Zhang, Y.-H., Carmichael, G. R., Wiedensohler, A., Andreae, M. O., Pöschl, U., 2012. Size-resolved measurement of the mixing state of soot in the megacity Beijing, China: diurnal cycle, aging and parameterization. Atmospheric Chemistry and Physics 12 (10), 4477-4491.

Chin, M., Ginoux, P., Kinne, S., Torres, O., Holben, B. N., Duncan, B. N., Martin, R. V., Logan, J. A., Higurashi, A., Nakajima, T., 2002. Tropospheric aerosol optical thickness from the GOCART model and comparisons with satellite and Sun photometer measurements. Journal of the Atmospheric Sciences 59 (3), 461-483. 
Chughtai, A. R., Brooks, M. E., Smith, D. M., 1996. Hydration of black carbon. Journal of Geophysical Research: Atmospheres (1984-2012) 101 (D14), 19505-19514.

Chughtai, A. R., Williams, G. R., Atteya, M., Miller, N. J., Smith, D. M., 1999. Carbonaceous particle hydration. Atmospheric Environment 33 (17), 2679-2687.

Cooke, W. F., Liousse, C., Cachier, H., Feichter, J., 1999. Construction of a $1^{\circ} \times 1^{\circ}$ fossil fuel emission data set for carbonaceous aerosol and implementation and radiative impact in the ECHAM4 model. Journal of Geophysical Research: Atmospheres 104 (D18), 22137-22162.

Cross, E., Onasch, T., Ahern, A., Wrobel, W., Slowik, J., Olfert, J., Lack, D., Massoli, P., Cappa, C., Schwarz, J., Spackman, J. R., Fahey, D., Sedlacek, A., Trimborn, A., Jayne, J., Freedman, A., Williams, L., Ng, N., Mazzoleni, C., Dubey, M., Brem, B., Kok, G., Subramanian, R., Freitag, S., Clarke, A., Thornhill, D., Marr, L., Kolb, C., Worsnop, D., Davidovits, P., Aug. 2010. Soot Particle Studies - Instrument Inter-Comparison-Project Overview. Aerosol Science and Technology 44 (8), 592-611.

Davis, D. D., Ravishankara, A. R., Fischer, S., 1979. $\mathrm{SO}_{2}$ oxidation via the hydroxyl radical: atmospheric fate of $\mathrm{HSO}_{\mathrm{x}}$ radicals. Geophysical Research Letters 6 (2), 113-116.

Drewnick, F., Hings, S., Decarlo, P., Jayne, J., Gonin, M., Fuhrer, K., Weimer, S., Jimenez, J., Demerjian, K., Borrmann, S., Worsnop, D., Jul. 2005. A New Time-of-Flight Aerosol Mass Spectrometer (TOF-AMS)- 
Instrument Description and First Field Deployment. Aerosol Science and Technology 39 (7), 637-658.

Fierce, L., Riemer, N., Bond, T. C., Dec. 2013. When is cloud condensation nuclei activity sensitive to particle characteristics at emission? Journal of Geophysical Research: Atmospheres 118 (24), 13,476-13,488.

Gross, S., Bertram, A. K., 2008. Reactive Uptake of $\mathrm{NO}_{3}, \mathrm{~N}_{2} \mathrm{O}_{5}, \mathrm{NO}_{2}, \mathrm{HNO}_{3}$, and $\mathrm{O}_{3}$ on Three Types of Polycyclic Aromatic Hydrocarbon Surfaces. The Journal of Physical Chemistry A 112 (14), 3104-3113.

Gysel, M., 2003. Properties of jet engine combustion particles during the PartEmis experiment: Hygroscopicity at subsaturated conditions. Geophysical Research Letters 30 (11), 1566.

Hagen, D. E., Trueblood, M. B., Podzimek, J., 1991. Combustion aerosol scavenging. Atmospheric Environment. Part A. General Topics 25 (11), $2581-2586$.

Hings, S. S., Wrobel, W. C., Cross, E. S., Worsnop, D. R., Davidovits, P., Onasch, T. B., 2008. CCN activation experiments with adipic acid: effect of particle phase and adipic acid coatings on soluble and insoluble particles. Atmospheric Chemistry and Physics 8 (14), 3735-3748.

Hough, A. M., Derwent, R. G., 1990. Changes in the global concentration of tropospheric ozone due to human activities. Nature 344 (6267), 645-648.

Kang, E., Root, M. J., Toohey, D. W., Brune, W. H., 2007. Introducing the concept of Potential Aerosol Mass (PAM). Atmospheric Chemistry and Physics 7 (22), 5727-5744. 
Khalizov, A. F., Lin, Y., Qiu, C., Guo, S., Collins, D., Zhang, R., 2013. Role of OH-Initiated Oxidation of Isoprene in Aging of Combustion Soot. Environmental Science and Technology 47 (5), 2254-2263.

Khalizov, A. F., Zhang, R., Zhang, D., Xue, H., Pagels, J., Mcmurry, P. H., 2009. Formation of highly hygroscopic soot aerosols upon internal mixing with sulfuric acid vapor. Journal of Geophysical Research 114 (D5), D05208.

Lambe, A. T., Ahern, A. T., Williams, L. R., Slowik, J. G., Wong, J. P. S., Abbatt, J. P. D., Brune, W. H., Ng, N. L., Wright, J. P., Croasdale, D. R., Worsnop, D. R., Davidovits, P., Onasch, T. B., 2011a. Characterization of aerosol photooxidation flow reactors: heterogeneous oxidation, secondary organic aerosol formation and cloud condensation nuclei activity measurements. Atmospheric Measurement Techniques 4 (3), 445-461.

Lambe, A. T., Onasch, T. B., Massoli, P., Croasdale, D. R., Wright, J. P., Ahern, A. T., Williams, L. R., Worsnop, D. R., Brune, W. H., Davidovits, P., 2011b. Laboratory studies of the chemical composition and cloud condensation nuclei (CCN) activity of secondary organic aerosol (SOA) and oxidized primary organic aerosol (OPOA). Atmospheric Chemistry and Physics 11 (17), 8913-8928.

Lance, S., Medina, J., Smith, J., Nenes, A., 2006. Mapping the Operation of the DMT Continuous Flow CCN Counter. Aerosol Science and Technology 40 (4), 242-254.

Liu, D., Allan, J., Whitehead, J., Young, D., Flynn, M., Coe, H., Mcfiggans, 
G., Fleming, Z. L., Bandy, B., 2013. Ambient black carbon particle hygroscopic properties controlled by mixing state and composition. Atmospheric Chemistry and Physics 13 (4), 2015-2029.

Liu, D., Flynn, M., Gysel, M., Targino, A., Crawford, I., Bower, K., Choularton, T., Jurányi, Z., Steinbacher, M., Hüglin, C., Curtius, J., Kampus, M., Petzold, A., Weingartner, E., Baltensperger, U., Coe, H., 2010. Single particle characterization of black carbon aerosols at a tropospheric alpine site in Switzerland. Atmospheric Chemistry and Physics 10 (15), 7389-7407.

Ma, Y., Brooks, S. D., Vidaurre, G., Khalizov, A. F., Wang, L., Zhang, R., 2013. Rapid modification of cloud-nucleating ability of aerosols by biogenic emissions. Geophysical Research Letters 40 (23), 6293-6297.

Mahowald, N., 2011. Aerosol Indirect Effect on Biogeochemical Cycles and Climate. Science 334 (6057), 794-796.

Mao, J., Ren, X., Brune, W., Olson, J., Crawford, J., Fried, A., Huey, L., Cohen, R., Heikes, B., Singh, H., 2009. Airborne measurement of $\mathrm{OH}$ reactivity during INTEX-B. Atmospheric Chemistry and Physics 9 (1), 163-173.

Mei, F., Setyan, A., Zhang, Q., Wang, J., 2013. CCN activity of organic aerosols observed downwind of urban emissions during CARES. Atmospheric Chemistry and Physics 13 (24), 12155-12169.

Moffet, R., Prather, K., 2009. In-situ measurements of the mixing state and optical properties of soot with implications for radiative forcing estimates. Proceedings of the National Academy of Sciences 106 (29), 11872. 
Ohata, S., Moteki, N., Schwarz, J., Fahey, D., Kondo, Y., 2013. Evaluation of a Method to Measure Black Carbon Particles Suspended in Rainwater and Snow Samples. Aerosol Science and Technology 47 (10), 1073-1082.

Petters, M., Kreidenweis, S., 2007. A single parameter representation of hygroscopic growth and cloud condensation nucleus activity. Atmospheric Chemistry and Physics 7 (8), 1961-1971.

Petters, M. D., Kreidenweis, S. M., Prenni, A. J., Sullivan, R. C., Carrico, C. M., Koehler, K. A., Ziemann, P. J., 2009. Role of molecular size in cloud droplet activation. Geophysical Research Letters 36 (22), L22801.

Pierce, J. R., Leaitch, W. R., Liggio, J., Westervelt, D. M., Wainwright, C. D., Abbatt, J. P. D., Ahlm, L., Al-Basheer, W., Cziczo, D. J., Hayden, K. L., Lee, A. K. Y., Li, S.-M., Russell, L. M., Sjostedt, S. J., Strawbridge, K. B., Travis, M., Vlasenko, A., Wentzell, J. J. B., Wiebe, H. A., Wong, J. P. S., Macdonald, A. M., 2012. Nucleation and condensational growth to $\mathrm{CCN}$ sizes during a sustained pristine biogenic SOA event in a forested mountain valley. Atmospheric Chemistry and Physics 12 (7), 3147-3163.

Podzimek, J., Trueblood, M. B., Hagen, D. E., 1991. Condensation nuclei activation or deactivation by deposited insoluble particles. Atmospheric Environment. Part A. General Topics 25 (11), 2587-2591.

Pruppacher, H., Klett, J., 1980. Microphysics of Clouds and Precipitation. D. Reidel.

Qiu, C., Khalizov, A. F., Zhang, R., 2012. Soot Aging from OH-Initiated Ox- 
idation of Toluene. Environmental Science and Technology 46 (17), 94649472.

Ramanathan, V., Carmichael, G., 2008. Global and regional climate changes due to black carbon. Nature Geoscience 1 (4), 221-227.

Reddy, M. S., Boucher, O., 2007. Climate impact of black carbon emitted from energy consumption in the world's regions. Geophysical Research Letters 34 (11), L11802.

Rickards, A. M. J., Miles, R. E. H., Davies, J. F., Marshall, F. H., Reid, J. P., 2013. Measurements of the Sensitivity of Aerosol Hygroscopicity and the $\kappa$ Parameter to the $\mathrm{O} / \mathrm{C}$ Ratio. The Journal of Physical Chemistry A 117 (51), 14120-14131.

Roberts, G. C., Nenes, A., 2005. A Continuous-Flow Streamwise ThermalGradient CCN Chamber for Atmospheric Measurements. Aerosol Science and Technology 39 (3), 206-221.

Schwarz, J. P., Gao, R. S., Fahey, D. W., Thomson, D. S., Watts, L. A., Wilson, J. C., Reeves, J. M., Darbeheshti, M., Baumgardner, D. G., Kok, G. L., Chung, S. H., Schulz, M., Hendricks, J., Lauer, A., Kärcher, B., Slowik, J. G., Rosenlof, K. H., Thompson, T. L., Langford, A. O., Loewenstein, M., Aikin, K. C., 2006. Single-particle measurements of midlatitude black carbon and light-scattering aerosols from the boundary layer to the lower stratosphere. Journal of Geophysical Research 111 (D16), D16207.

Schwarz, J. P., Gao, R. S., Perring, A. E., Spackman, J. R., Fahey, D. W., Mar. 2013. Black carbon aerosol size in snow. Scientific Reports 3, 1-5. 
Schwarz, J. P., Spackman, J. R., Gao, R. S., Perring, A. E., Cross, E., Onasch, T. B., Ahern, A., Wrobel, W., Davidovits, P., Olfert, J., Dubey, M. K., Mazzoleni, C., Fahey, D. W., 2010. The Detection Efficiency of the Single Particle Soot Photometer. Aerosol Science and Technology 44 (8), 612-628.

Shiraiwa, M., Garland, R. M., Pöschl, U., 2009. Kinetic double-layer model of aerosol surface chemistry and gas-particle interactions (K2-SURF): degradation of polycyclic aromatic hydrocarbons exposed to $\mathrm{O}_{3}, \mathrm{NO}_{2}, \mathrm{H}_{2} \mathrm{O}, \mathrm{OH}$ and $\mathrm{NO}_{3}$. Atmospheric Chemistry and Physics 9 (24), 9571-9586.

Slowik, J. G., Cross, E. S., Han, J.-H., Kolucki, J., Davidovits, P., Williams, L. R., Onasch, T. B., Jayne, J. T., Kolb, C. E., Worsnop, D. R., 2007. Measurements of Morphology Changes of Fractal Soot Particles using Coating and Denuding Experiments: Implications for Optical Absorption and Atmospheric Lifetime. Aerosol Science and Technology 41 (8), 734-750.

Sullivan, R., Moore, M., Petters, M., Kreidenweis, S., Roberts, G., Prather, K., 2009. Effect of chemical mixing state on the hygroscopicity and cloud nucleation properties of calcium mineral dust particles. Atmospheric Chemistry and Physics 9, 3303-3316.

Tritscher, T., Jurányi, Z., Martin, M., Chirico, R., Gysel, M., Heringa, M. F., Decarlo, P. F., Sierau, B., Prévôt, A. S. H., Weingartner, E., Baltensperger, U., 2011. Changes of hygroscopicity and morphology during ageing of diesel soot. Environmental Research Letters 6 (3), 034026.

Westervelt, D. M., Pierce, J. R., Riipinen, I., Trivitayanurak, W., Hamed, A., 
Kulmala, M., Laaksonen, A., Decesari, S., Adams, P. J., 2013. Formation and growth of nucleated particles into cloud condensation nuclei: modelmeasurement comparison. Atmospheric Chemistry and Physics 13 (15), 7645-7663.

Wittbom, C., Pagels, J. H., Rissler, J., Eriksson, A. C., Carlsson, J. E., Roldin, P., Nordin, E. Z., Nilsson, P. T., Swietlicki, E., Svenningsson, B., 2014. Cloud droplet activity changes of soot aerosol upon smog chamber ageing. Atmospheric Chemistry and Physics Discussions 14 (7), 8851-8914.

Yli-Juuti, T., Nieminen, T., Hirsikko, A., Aalto, P. P., Asmi, E., Hõrrak, U., Manninen, H. E., Patokoski, J., Dal Maso, M., Petäjä, T., Rinne, J., Kulmala, M., Riipinen, I., 2011. Growth rates of nucleation mode particles in Hyytiälä during 2003 - 2009: variation with particle size, season, data analysis method and ambient conditions. Atmospheric Chemistry and Physics 11 (24), 12865-12886.

Zuberi, B., 2005. Hydrophilic properties of aged soot. Geophysical Research Letters 32 (1), L01807. 


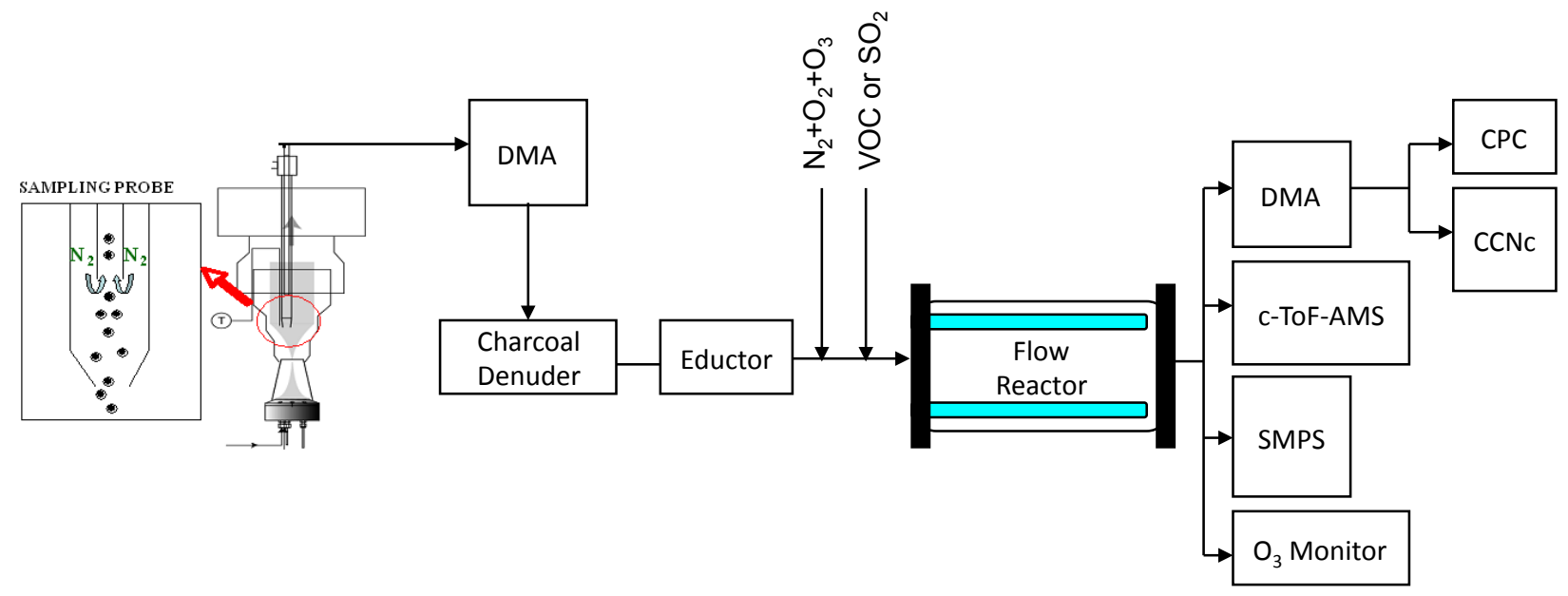

Figure 1: Schematic showing production, processing, and characterization of ethylene flame soot particles. Ethylene combustion in $\mathrm{O}_{2}$ by a McKenna flat burner produces soot that is sampled using a mini-eductor to extract polydisperse soot particles from the tip of the flame into a Differential Mobility Analyzer (DMA) where the particles are size-selected. The flow then passes through an annular charcoal denuder. Sample flow is then mixed with humidified $\mathrm{N}_{2}, \mathrm{O}_{2} / \mathrm{O}_{3}$, and gasphase SOA precursor and aged in a Potential Aerosol Mass (PAM) reactor prior to characterization with Scanning Mobility Particle Sizer (SMPS), compact timeof-flight aerosol mass spectrometer (c-ToF-AMS), and cloud condensation nucleus counter (CCNC). 


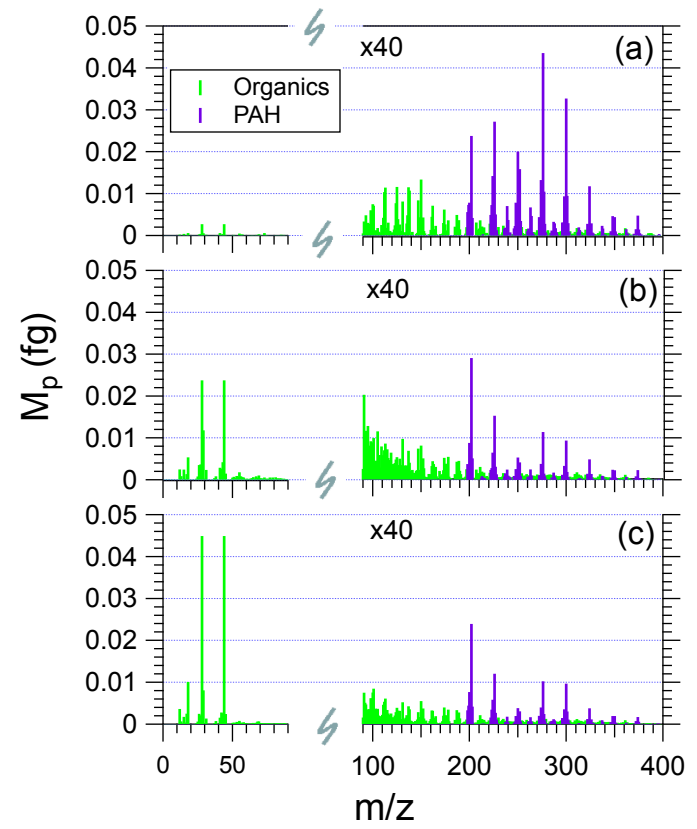

Figure 2: AMS spectra of non-refractory components of (a) nascent soot and soot exposed to $\mathrm{OH}$ at exposures of (b) $2.5 \times 10^{11}$ and (c) $1.3 \times 10^{12}$ molec $\mathrm{cm}^{-3}$ sec. Spectra are normalized to particle mass $\left(\mathrm{M}_{p}\right)$. Signals at $m / z>90$ are scaled by a factor of 40 to present spectra on the same display. 


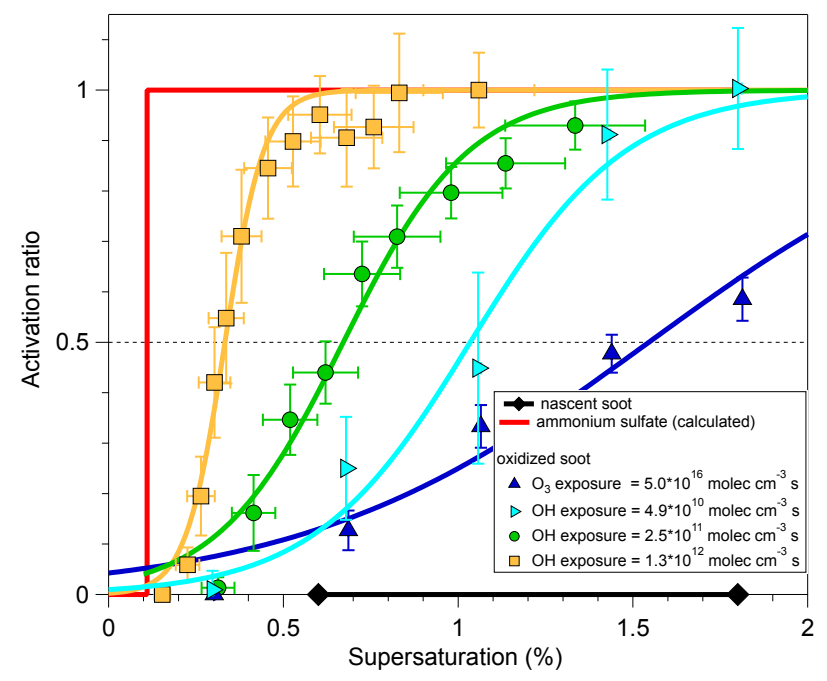

Figure 3: CCN activation curves for nascent soot, soot oxidized by $\mathrm{O}_{3}$, and soot oxidized by $\mathrm{OH}$. The mobility diameter of the soot particles prior to activation was $222 \mathrm{~nm}$. Error bars indicate $\pm 1 \sigma$ of replicate measurements. The calculated CCN activation of ammonium sulfate with the same volume equivalent diameter $\left(D_{v e}=124 \mathrm{~nm}\right)$ is shown for reference. 


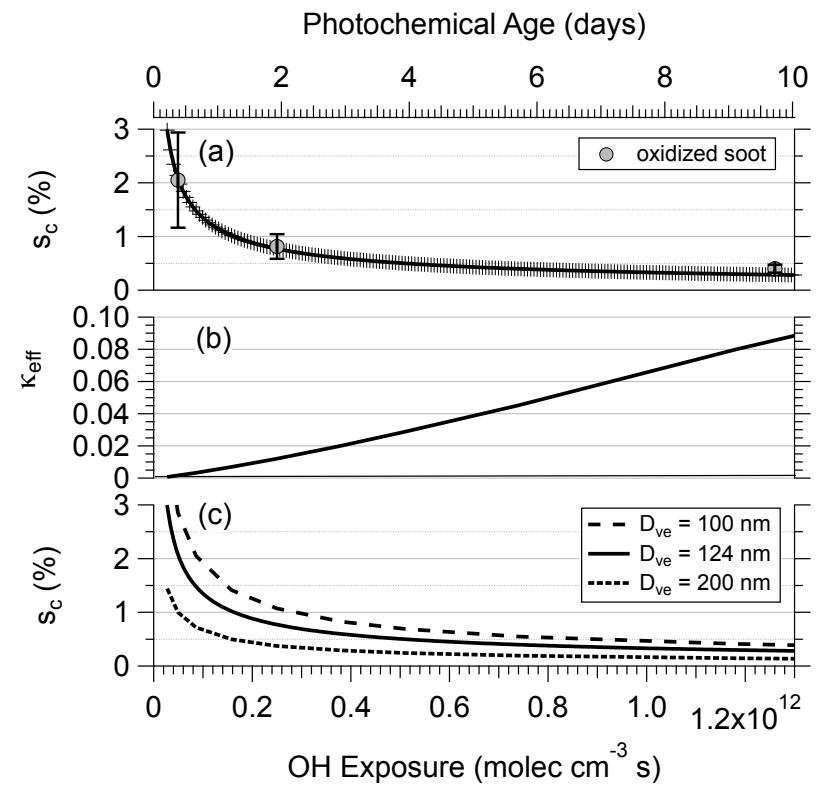

Figure 4: (a) Measured CCN critical supersaturation $\left(s_{c}\right)$ values (solid line is best-

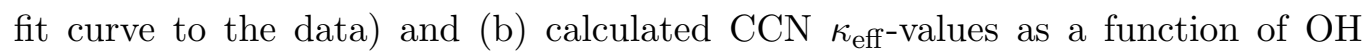
exposure for oxidized soot particles with $D_{v e}=124 \mathrm{~nm}$. (c) Calculated $s_{c}$ values as a function of $\mathrm{OH}$ exposure for oxidized soot particles with $D_{v e}=100 \mathrm{~nm}$ and $200 \mathrm{~nm}$ bracketing the measured $\mathrm{D}_{v e}$ (see Section 3.3). Equivalent photochemical age is shown on the top axis assuming an average atmospheric $\mathrm{OH}$ concentration of $1.5 \times 10^{6}$ molec $\mathrm{cm}^{-3}$. Error bars indicate $\pm 1 \sigma$ of replicate measurements. 


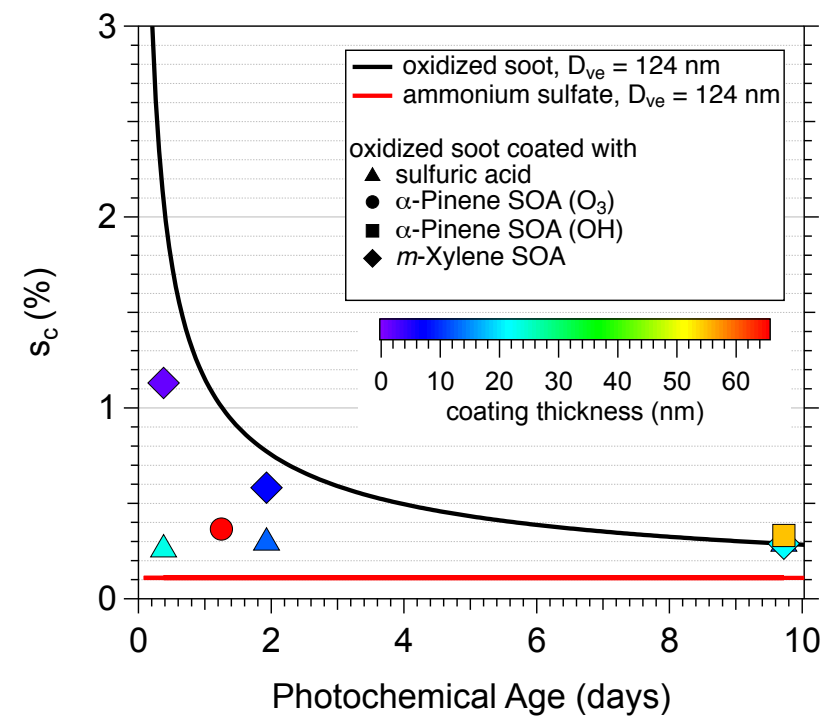

Figure 5: Measured CCN critical supersaturation $\left(s_{c}\right)$ values as a function of photochemical age for oxidized soot particles with initial volume equivalent diameter $D_{v e}=124 \mathrm{~nm}$ coated by sulfuric acid, $\alpha$-pinene SOA, and $m$-xylene SOA. For ozonolysis conditions, photochemical age was calculated assuming an average atmospheric $\mathrm{O}_{3}$ concentration of $5 \times 10^{11}$ molec $\mathrm{cm}^{-3}$. 